\title{
Based on Weighted Relative Deviation Distance of Anti-ship Missile Fuzzy Comprehensive Operational Capability Evaluation
}

\author{
Zhang Lin \\ Department of missile, Dalian Naval Academy, Dalian, 116018,China \\ E-mail: mailbox1015@126.com
}

\begin{abstract}
Against anti-ship missile weapon system combat capability evaluation methods of present situation, the paper proposes a evaluation method based on weighted relative deviation distance. In the multi-factor fuzzy comprehensive evaluation, on the basis of fuzzy matrix, calculate the relative deviation of relative deviation distance. Through calculation of each system and the ideal system, assess the relative deviation distance composite operational capability of antiship missile weapon system. This method can make full use of expert judgment information fuzziness and gray sex, and make the anti-ship missile operational effectiveness evaluation result more objective and accurate.
\end{abstract}

Keywords-Anti-ship missiles; Operational effectiveness; The fuzzy evaluation; Minimum distance method

\section{INTRODUCTION}

Anti-ship missile operational effectiveness assessment is a fuzzy multi-factor comprehensive evaluation problem, whose assessment factors, evaluation standard and complex characteristics of traditional evaluation methods are difficult to obtain accurate evaluation results. In previous literature, the effectiveness evaluation of weakness exists in two aspects: one is the less consideration of the attack-defense confrontation situation of missile combat effectiveness, one is the influence of evaluation which is often be the result of the static, however the anti-ship missile operational effectiveness assessment of the actual is a kind of static and dynamic combination evaluation process ${ }^{[1-4]}$. It is because that the different countries for weapon and equipment development idea is different that the anti-ship missile has very big difference on operational effect and judgment standard which are difficult to unity, such as Russia's pursuit of over-the-horizon, the development of the supersonic, the pursuit of stealth sex, intelligent direction, etc. So in order to solve the above deficiencies, based on weighted relative deviation distance method is proposed to evaluate comprehensive anti-ship missile weapon system combat effectiveness, so as to realize the quantitative analysis of anti-ship missile operational effectiveness assessment.

\section{WEIGHTED RELATIVE DEVIATION DISTANCE EVALUATION METHOD}

A. The principle of multi-factor fuzzy evaluation model is set up

Multifactor fuzzy assessment model should be in accordance with the following principles: firstly, the selection of various types of missile weapon system performance indicators should be included to the comprehensive influence on operational effectiveness of main indicators; Secondly, the selection of various types of missile weapon system performance indicators should be as far as possible with accurate data; Thirdly, the performance of the missile weapon system is very much, which should not only consider the credibility of evaluation, but also consider convenient calculation, general to determine about 15; Fourthly, to select the need to deal with the fuzzy performance index, use expert scoring method is a numerical value.

\section{B. Determine the parameter values of evaluation factors}

Domain evaluation theory $\mathrm{X}$ is to accept a collection of various air ship missile weapon system evaluation, and comprehensive air missile weapon system combat effectiveness factors which play an important role in the index set which is $\left\{f_{1}, f_{2}, \cdots, f_{n}\right\}$ :, various types of air ship missile weapon system factors index vector are as follows: $\left(f_{1 j}, f_{2 j}, \cdots, f_{n j}\right)^{T}, j=1,2, \cdots, m \cdot f_{i j}$ is the $\mathrm{j}$ type air ship missile weapon system of i factor index, according to $f_{i j}$, the available $\mathrm{m}$ kind of empty $\mathrm{n}$ factor index matrix of anti-ship missile weapon system:

$$
F=\left[\begin{array}{llll}
f_{11} f_{12} & \cdots & f_{1 m} \\
f_{21} f_{22} & \cdots & f_{2 m} \\
\vdots & \vdots & \vdots & \vdots \\
f_{n 1} f_{n 2} & \cdots & f_{n m}
\end{array}\right]
$$

C. The evaluating steps of minimum weighted relative deviation distance method

Minimum weighted relative deviation distance method is to find out the evaluation indexes of the best performers in various factors concerning domain the ideal system, by calculating the system and the relative 
deviation of the distance to the ideal system for air ship integrated operational effectiveness of missile weapon system evaluation methods, which mainly includes the relative deviation fuzzy matrix and computing the relative deviation distance of two parts.

When various types of air ship missile weapon system factors and indexes are as quantitative indexes:

$$
\delta_{i j}=\frac{\left|f_{i}^{0}-f_{i j}\right|}{f_{i \max }-f_{i \min }},(\mathrm{i}=1,2, \ldots, \mathrm{n} ; \mathrm{j}=1,2, \ldots, \mathrm{m})
$$

Type: $f_{i \max }$ is various factors to the empty anti-ship missile weapon system is the $\mathrm{i}$ acquire the biggest indexes, namely $f_{i \max }=\max \left(f_{11}, f_{12}, \cdots, f_{i m}\right), f_{i \text { min }}$ is various factors to the empty anti-ship missile weapon system is the acquire the smallest indexes, namely:

$$
f_{i \text { min }}=\min \left(f_{11}, f_{12}, \cdots, f_{\text {im }}\right)
$$

When the factor index $f_{i}$ is positive index (the higher the factors index is, the greater the integrated missile weapon system operational effectiveness will be) $f_{i}^{0}=f_{\max }$. When factor index $f_{i}$ is negative index (the higher the factors index is, the greater the missile weapon system operational effectiveness will be), $f_{i}^{0}=f_{\min }$ and draw the relative deviation of fuzzy matrix $\delta_{i j}$ :

$$
\widetilde{\Delta}=\left[\begin{array}{cccc}
\delta_{11} & \delta_{12} & \cdots & \delta_{1 m} \\
\delta_{21} & \delta_{22} & \cdots & \delta_{2 m} \\
\vdots & \vdots & \vdots & \vdots \\
\delta_{n 1} & \delta_{n 2} & \cdots & \delta_{n m}
\end{array}\right]
$$

Use Delphi method, evaluation of the weight coefficient of each influence factor $a_{i}$ : the factors is of important degree of fuzzy subset $\tilde{A}=\left(a_{1}, a_{2}, \ldots, a_{n}\right)$, calculate each empty anti-ship missile weapon system factors index vector and $\mathrm{m}$, empty anti-ship missile weapon system is $\mathrm{n}$ index standard values of the vector, the weighted relative deviation distance between $f^{0}=\left(f_{1}^{0}, f_{2}{ }^{0}, \cdots, f_{n}{ }^{0}\right)$ is:

$$
d_{j}=d\left(u_{j}, f^{0}\right)=\frac{1}{a} \sqrt{\sum_{i=1}^{n}\left(a_{i} \cdot \delta_{i j}\right)^{2}}
$$

By m, empty anti-ship missile weapon system is $n$ index standard vector, consisting of empty anti-ship missile weapon system which is proposed for the ideal system. $M$ is a kind of empty anti-ship missile weapon system. Therefore, the ideal system between the minimum weighted relative deviation distance is $d_{j}$, corresponding to the empty vessel best integrated operational effectiveness of missile weapon system prioritize.

Anti-ship missiles at the end of the jump dive attack can effectively avoid artillery systems, which is the end of the anti-ship missile penetration, which can use one of the effective way and can improve the damage efficiency of ships. Missile at a certain angle and angular velocity in this section, climb to a certain height, and then the missile warhead rapid rotation, turn angle to attack with large subduction dives until hitting the target.

When the ballistic cruise anti-ship missile is higher, when entering the homing stage, missile target with certain dive angle, both to improve the accuracy and can improve the ability of damage, usually adopt a highly program control missile fall high dive.

\section{APPLICATION EXAMPLE}

This chosen case have five kinds of typical air to ship missile weapon system: "cormorants" (Germany), "fork" whaling AGM-84-a (US), air-launched "glory" (Taiwan), "flying fish" AM39 II (France), "Uranus" air-launched X35 (Russia) as evaluation samples.

\section{A. Establish the empty ship missile weapon system combat effectiveness factor index value matrix}

Empty first establishes the level of the anti-ship missile weapon system combat effectiveness analysis: synthesis of missile weapon system operational effectiveness refers that the system can successfully complete its mission, and the ability can meet the operational needs. By hierarchical analysis, the operational effectiveness of missile weapon system of the empty ship is mainly composed of the following decision analytic hierarchy model, which is shown as Table 1.

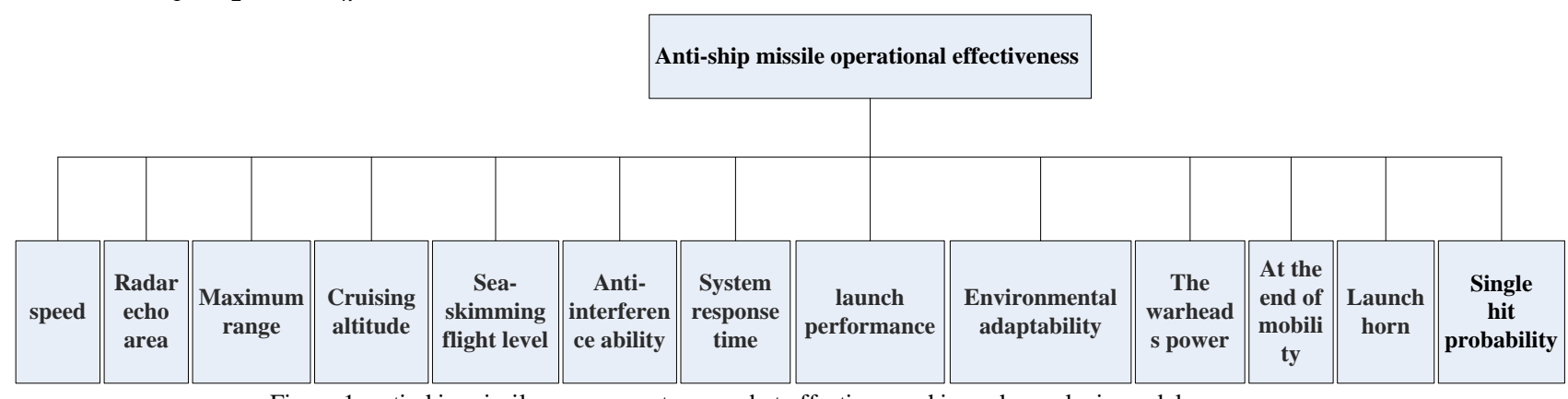

Figure 1. anti-ship missile weapon system combat effectiveness hierarchy analysis model 
To missile weapon system is obtained by data access estimation results). performance indicators such as Table 2 (with $*$ for expert

Table I each performance of the anti-ship missile weapon system

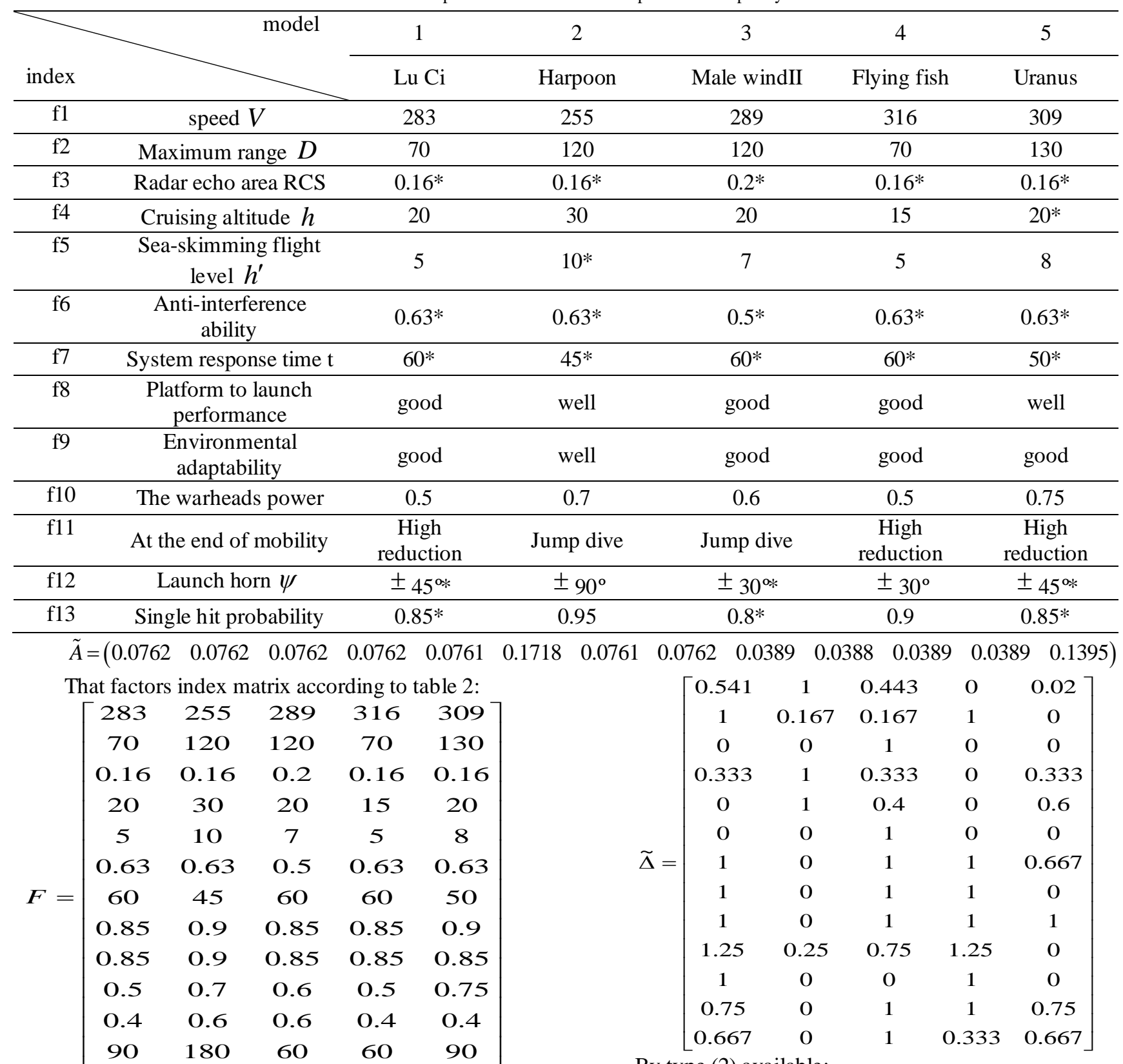

$\left[\begin{array}{lllll}0.85 & 0.95 & 0.8 & 0.9 & 0.85\end{array}\right]$

The relationship is: $\mathrm{f} 1, \mathrm{f} 2, \mathrm{f} 6, \mathrm{f} 8, \mathrm{f} 9, \mathrm{f} 10, \mathrm{f} 11, \mathrm{f} 12, \mathrm{f} 13$; Negative indicators have: $f 3, f 4, f 5, f 7$.

Various comprehensive air ship missile weapon system operational effectiveness factors of standard value vector is:

$$
f^{0}=\left(\begin{array}{l}
316,130,0.16,15,5,0.63,45,0.9, \\
0.9,0.75,0.6,180,0.95
\end{array}\right)
$$

\section{B. Calculate the weighted relative deviation distance}

By Type (1), it can be concluded that the relative deviation of fuzzy matrix
By type (2) available:

$$
\begin{aligned}
& d_{1}=d\left(u_{1}, f^{0}\right)=13 \sqrt{\sum_{i=1}^{13}\left(a_{i} \cdot \delta_{i 1}\right)^{2}}=2.42 \\
& d_{2}=d\left(u_{2}, f^{0}\right)=13 \sqrt{\sum_{i=1}^{13}\left(a_{i} \cdot \delta_{i 2}\right)^{2}}=1.73, \\
& d_{3}=d\left(u_{3}, f^{0}\right)=13 \sqrt{\sum_{i=1}^{13}\left(a_{i} \cdot \delta_{i 3}\right)^{2}}=3.51, \\
& d_{4}=d\left(u_{4}, f^{0}\right)=13 \sqrt{\sum_{i=1}^{13}\left(a_{i} \cdot \delta_{i 4}\right)^{2}}=2.12, \\
& d_{5}=d\left(u_{5}, f^{0}\right)=13 \sqrt{\sum_{i=1}^{13}\left(a_{i} \cdot \delta_{i 5}\right)^{2}}=1.66
\end{aligned}
$$

So it can be seen from the above results using this evaluation method to the five empty anti-ship missile 
weapon system of integrated operational effectiveness finally sorted result for $\mathrm{d} 5<\mathrm{d} 2<\mathrm{d} 4<\mathrm{d} 1<\mathrm{d} 3$, that is to say, the five empty anti-ship missile weapon system combat efficiency of the comprehensive evaluation results sorted as: Uranus $>>$ whaling fork flying fish $>$ cormorants $>$ glory. II.

\section{Evaluation results analysis}

The calculation result shows that "Uranus" anti-ship missile weapon system in Russia and the United States "whaling fork" anti-ship missile weapon system operational effectiveness roughly, compared with "Uranus" slightly better, because the speed and range advantage is more obvious, and the "fork" whaling are at a disadvantage lies in the speed and range, especially the speed difference between Uranus' speed is larger, the system response time of the advantage of environmental adaptation ability os "whaling fork" is shorter. The end of the motor ability is strong, and at the end of the motor performance of Uranus' needs to be improved. "Flying fish" is a kind of typical French navy anti-ship missiles, and it is also the world's biggest and most used in actual combat of a missile. The advantage of "Flying fish" is its speed, the supersonic speed has produced significant effect on the improvement of its operational effectiveness. "Uranus" with Russia and the United States "whaling fork" has a clear disadvantage in the range than "flying fish". "Cormorants" is developed by Germany empty antiship missile weapon system, in terms of Germany's industrial technology level, "cormorants" comprehensive missile weapon system combat effectiveness on the low side, fully reflects the predominantly defensive combat ideas in Germany. "II" empty anti-ship missile weapon system as the naval battle missile weapon and equipment of Taiwan's increase in range should not be ignored.

\section{CONCLUSION}

Use minimum weighted relative deviation distance method of fuzzy multiple factors under the condition of the empty ship integrated operational effectiveness of missile weapon system evaluation, for the selected five empty ship integrated operational effectiveness of missile weapon system, the results are more close to the actual situation. This method takes into account the empty antiship missile weapon system combat effectiveness of the main index and comprehensive surface-to-air missiles. It evaluates the operational effectiveness of weapon system. The credibility is high, the method is simple and practical; Selection of indicators, the higher the reliability theory is, the more indicators of the conclusion are. But in foreign, the operational effectiveness evaluation in the course of the parameters credibility to the missile weapon system is not high, too many parameters are selected indicators backfire. This method can be extended to other types of comprehensive operational effectiveness evaluation of missile weapon system, and should be paid attention to when selecting the main parameter to reflect the characteristics of different types of missile weapon system, which has been widely applied.

\section{REFERENCES}

[1] WANG Hong-jun, CHI Zhong-xian.Shipboard hard and soft weapon anti-missile decision-makingoptimization based on collaboration[J], Control and Decision, 2007, 22 (3) : 299303

[2] Liang Bo, Duan Ran.Fire distribution model based on feasible direction algorithm $[\mathrm{J}]$, Command Information System and Technology, 2013,4 (2) :30-32

[3] Sarit Kraus.Negotiation and cooperation in mulfi-ageat environments.Artificial Intelligence. 1997 : 79-97

[4] MA Liang, QING Zuo-sheng, ZHANG Lin.Formation comprehensive cooperative air defense multi-stage decision optimization modeling[J], Tactical Missile Technology, 2013,9 (5) :25-28

[5] LIU Wei dong, JIANG Qing shan, LI Yong.Fire distribution of the network centric ship-to-air missile based on earlier damage[J],Ship Science And Technology, 2011,33 (2) :98-101

[6] CHEN Guo sheng, JIA $\mathrm{Zi}$ ying.Research on coordinated air defense firepower distribution model for warships[J], Command ControI\& Simulation, 2011,33 (12) :13-15

[7] XU Z S. Multiple-attribute group decision making with different formats of preference information on attributes [J]. IEEE Trans on System, Man, and Cybernetics-Part B: Cybernetics, 2007, 37 (6) : 1500-1511.

[8] A.Hadi-Vencheh, M.Allame. On the relation between a fuzzy number and its centroid [J].Comput. Math. Appl, 2010, 59: 3578-3582

[9] Lee Z J, Su S F, Lee C Y. Efficiently solving general weapontarget assignment problem by genetic algorithms with greedy eugenics[J].IEEE Transactions on Systems, Man and CyberneticsPartB, 2003, 33(1) : 113-121.

[10] Abdollah, Mahdi. Seclusion-Factor Method to solve fuzzymultiple criteria decision-making problems [J].IEEE Trans on Fuzzy Systems, 2011, 19 (2): 201-209.

[11] Beynon M J, Bruce Curry, Peter Morgan. The Dempster-Shafer theory of evidence: An alternative approach to multi-criteria decision modeling[J]. Omega, 2000, 28(1):37-50.

[12] Beynon M J. DS/AHP method: A mathematical analysis,including an understanding of uncertainty[J]. European $\mathrm{J}$ of Operational Research, 2002, 140(1): 148-164.

[13] Shargel B, Sayama H, Epstein I R, etal. Optimi zation of robustness and connectivity in complex networks[J]. Phys. Rev. Lett., 2003, 90(6): 068701

[14] Paul G, Tanizawa T, Havlin S, etal. Optimization of robustness of complex networks[J]. Eur. Phys. J. B, 2004, 38(2): 187-191

[15] Valente A X C N, Sarkar A, Stone H A. Two-peak and three-peak optimal complex network s[J]. Phys. Rev. Lett. , 2004, 92(11): 118702

[16] Tanizawa T, Paul G, Cohen R, etal. Optimization of network robustness to waves of targeted and random attacks[J]. Phys. Rev. E, 2005, 71(4): 047101

[17] Solé R V, Alverde S V. Information theory of complex networks: on evolution and architectural constraints[J]. Lect. Notes. Phys. , 2004, 650: 189-207

[18] Wang B, Tang H W, Guo C H, et al. Entropy Optimization of Scale-free Network s Robustness to Random Failures[J ]. Physica A, 2005, 363: 591-596

[19] Beygelzimer A, Grinstein G. Improving network robustness by edge modification[J]. Physica A, 2005, 357: 593-612

[20] Rezaei B A, Sarshar N, Roychowdhury V P, etal. Disaster management in power-law networks:

[21] CALLAWAYDS, NEWMANMEJ, STROGATEZSH, et al. Network robustness and fragility: percolation on random graphs[J] . Phys. Rev. Lett. , 2000 , 85(25): 5468-5471 